\title{
Characteristics, distribution and ecological risk assessment of phosphorus in surface sediments from different ecosystems in Eastern China: A ${ }^{31}$ P-nuclear magnetic resonance study
}

\author{
Wenqiang Zhang ${ }^{\mathrm{a}}$, Baoqing Shan ${ }^{\mathrm{a}, *}$, Jie $\mathrm{Li}^{\mathrm{a}}{ }^{\mathrm{a}}$, Wenzhong Tang ${ }^{\mathrm{a}}$, Xin Jin ${ }^{\mathrm{c}}$, Hong Zhang ${ }^{\mathrm{a}}$, \\ Yuekui Ding ${ }^{\mathrm{a}, \mathrm{b}}$, Yuanyue Wang ${ }^{\mathrm{b}, \mathrm{d}}$, Xiaolei Zhu ${ }^{\mathrm{a}, \mathrm{b}}$ \\ a State Key Laboratory on Environmental Aquatic Chemistry, Research Center for Eco-Environmental Science, Chinese Academy of Science, Beijing, 100085, PR \\ China \\ ${ }^{\mathrm{b}}$ University of Chinese Academy of Science, Beijing, PR China \\ ${ }^{\mathrm{c}}$ Hebei University of Engineering, Hebei Handan 056038, PR China \\ d Department of Water Pollution Control Technology, Chinese Academy of Science, Beijing 100085, PR China
}

\section{A R T I C L E I N F O}

\section{Article history:}

Received 26 March 2014

Received in revised form 12 November 2014

Accepted 28 November 2014

Available online 11 December 2014

\section{Keywords:}

Phosphorus

Eutrophication

${ }^{31}$ P-NMR

ERI

Sediment

\begin{abstract}
A B S T R A C T
Surface sediments in different ecosystems (lake, river, reservoir, estuary and wetland) in Eastern China were extracted with $\mathrm{NaOH}$-EDTA, and the extracts were analyzed by ${ }^{31} \mathrm{P}-\mathrm{NMR}$ to reveal the phosphorus (P) species distribution. The P release risk was also assessed by sorption experiments. The river sediments accumulated significant amounts of P compared with other sediments. The organic phosphorus (Po) concentration in the estuarine sediment was lower than that in other sediments. Two P compounds classes (phon-P and mono-P) and five $\mathrm{P}$ compounds were detected in the sediments. Ortho-P (83.397.6\%) was the dominant $\mathrm{P}$ compounds and mono-P (1.1-18.0\%) were the dominant Po compounds classes, while smaller amounts of DNA-P $(0-4.1 \%)$, pyro-P $(0-4.0 \%)$ and lipid-P $(0-0.8 \%)$ were found in the surface sediment. Poly-P and phon-P were detected only in site 11 (wetland), site 10 (wetland) and 11 , respectively. The ERI values, as a measure of eutrophication risk, were different in the various sediments, being greater than $25 \%$ in sites 1 (river), 3 (estuary) and 4 (estuary), and with values of 26,59 and $83 \%$, respectively. The Xm and ERI values fitted a power function $\left(R_{\mathrm{Xm}-\mathrm{ERI}}=0.89, p<0.01\right)$ and a positive correlation between Xm and OM in the sediment $\left(R_{\mathrm{Xm}-\mathrm{OM}}=0.84, p<0.01\right)$ indicated that the chemicalphysical conditions play a vital role in controlling $\mathrm{P}$ sorption and desorption.
\end{abstract}

(c) 2014 Elsevier B.V. All rights reserved.

\section{Introduction}

Phosphorus (P) is a vital element to all life and aquatic ecosystems. Excessive P inflow in the water column will accelerate primary productivity in the water leading to eutrophication (Wetzel, 2001; Paytan and McLaughlin, 2010). Eutrophication of aquatic ecosystems has become one of the most severe environmental problems, especially in developing countries, and is driven by the amount of nutrient inputs from untreated sewage and agricultural wastewater (Xu et al., 2010; Pernet-Coudrier et al., 2012). The consequences of eutrophication include algal blooms, oxygen depletion, fish kills, aquatic ecosystem deterioration and increasing water treatment costs to ensure freshwater is suitable for human use (Nyenje et al., 2010; Vörösmarty et al., 2010).

\footnotetext{
* Corresponding author. Tel.: +86 10 62849817; fax: +86 1062849817. E-mail address: bqshan@rcees.ac.cn (B. Shan).
}

Within the last two decades, China has become one of the fastest growing economies, with a GDP growth rate of nearly $10 \%$ (Liu and Raven, 2010). Meanwhile, the generation and consumption of P-containing compounds has dramatically increased. In particular, human activities associated with agriculture and industry has greatly accelerated the production of bioactive nutrients containing $\mathrm{P}(\mathrm{Qu}$ and Kroeze, 2010). Currently, the population density in Eastern China is over 400 people per square kilometer. The rapid population growth, industrial development and increased agricultural production have led to an increased inflow of untreated sewage and waste into the environment. As a result, anthropogenically mobilized $\mathrm{P}$ in watersheds enters rivers, lakes and marine systems, which increase the risk of surface water eutrophication (Pernet-Coudrier et al., 2012). Research has shown that the total P (TP) load in the Songhuajiang watershed was $4.05 \times 10^{4} \mathrm{t}$ in 2008 , which was caused mainly by man-made nonpoint source pollution and the load of $\mathrm{P}$ was $3.40 \times 10^{4} \mathrm{t}$, accounting for $83.94 \%$ of the TP load (Ma et al., 2011). High P 
concentrations were also found in the Zhujiang (Pearl) river estuary wetland, ranging from 648.9 to $1064.0 \mathrm{mg} \mathrm{kg}^{-1}$ in the surface sediment. These results showed that the potential risk of eutrophication in the wetland sediment was high (Wang et al., 2013a,b,b). The average concentration of TP in Taihu lake sediment (18 sites) was $648 \mathrm{mg} \mathrm{kg}^{-1}$, and the concentration of TP in Meiliang bay exceeded $1800 \mathrm{mg} \mathrm{kg}^{-1}$, which means that the sediment was a potential source of $\mathrm{P}$ for overlying water leading to likely eutrophication (Bai et al., 2009). The Haihe watershed, which includes many large cities such as Beijing and Tianjin, provides 30\% of China's wheat and 20\% of its corn, and the nutrient concentrations ( $\mathrm{N}$ and $\mathrm{P}$ ) in their rivers have drastically increased in the past 40 years (Hong and Luan, 1998; Shi et al., 2008).

There is significant diversity in the water ecosystems in Eastern China, as reflected in the rivers, wetlands, lakes, reservoirs and estuaries. Different water ecosystems have various P compounds which exhibit diverse $\mathrm{P}$ retention mechanism (Wang and Pant, 2010a,b,b). Lakes and reservoirs are considered a "sink" for such chemical species in the watershed, so appreciable P compounds are retained in the sediments of lakes and reservoirs (Zhang et al., 2009). Rivers are often considered the "corridor" of the watershed, which means that $\mathrm{P}$ might input to lake or ocean via river transportation. However, $\mathrm{P}$ is largely contained within the river sediment because of dams and the smooth grain particles in the flood plain, as in the Haihe river basin. There is, however, a lack of research on the occurrence and nature of $P$ species within such sediments and also little information on the associated ecological risk assessment at the regional scale.

To this end, different $\mathrm{P}$ compounds in the sediments were measured by ${ }^{31} \mathrm{P}$-nuclear magnetic resonance spectroscopy $\left({ }^{31} \mathrm{P}\right.$ NMR), a powerful, non-destructive and non-invasive technique for identifying chemical forms of $\mathrm{P}$. The technique enables multiple $\mathrm{P}$ compounds with distinct binding properties to be characterized simultaneously (Cade-Menun, 2005; Cade-Menun et al., 2006). Since the first application of ${ }^{31} \mathrm{P}-\mathrm{NMR}$ in soil analysis (Newman and Tate, 1980), many researches have been carried out for soil, manure and sediment (Cade-Menun and Liu, 2013; Toor et al., 2005; Ahlgren et al., 2006).

Several P compounds have been studied by ${ }^{31} \mathrm{P}-\mathrm{NMR}$, including phosphonate, orthophosphate, orthophosphate monoesters, orthophosphate diesters (lipids-P and DNA-P), pyrophosphate and polyphosphate (Cade-Menun, 2005). ${ }^{31} \mathrm{P}-\mathrm{NMR}$ spectroscopy can provide detailed information pertaining to $\mathrm{P}$ compounds and concentrations, which can contribute to a better understanding of $P$ transformation and recycling in the environment.

To date, many studies have focused only on $\mathrm{P}$ in rivers or lakes sediment; there is a lack of research at the regional scale including studies on wetlands, lakes, rivers and reservoirs. Thus, this study aims to provide a basis for understanding the characteristics and distribution of P compounds in surface sediments of Eastern China using ${ }^{31} \mathrm{P}-\mathrm{NMR}$. Experiments have also been performed to evaluate the ecological risk of $\mathrm{P}$ in surface sediments of the different ecosystems.

\section{Materials and methods}

\subsection{Site description}

Twelve surface sediments were collected from rivers (Songhuajiang River-site 1, Haihe River-sites 5, 6 and Zhujiang River-site 12), lakes (Chaohu Lake-site 8 and Poyanghu Lake-site 9), reservoir (Miyun Reservoir-site 2), wetlands (Shijiuyang Wetlands-sites 10, 11 and Baiyangdian Wetland-site 7) and estuaries (Haihe estuarysites 3 and 4) (Fig. 1). The trophic status of the water bodies ranged from mesotrophic to hypereutrophic. The concentrations of TP ranged from 0.04 to $6.80 \mathrm{mg} \mathrm{L}^{-1}$ and water $\mathrm{pH}$ ranged from 6.8 to



Fig. 1. Location of the 12 sample sites in Eastern China. The sites were in Heilongjiang Province, Hebei Province, Beijing Municipality, Tianjin Municipality, Zhejiang Province, Anhui Province, Jiangxi Province, Guangdong Province. Sampling sites consisted of rivers, estuaries, reservoirs, wetlands and lakes.

8.5. The longitudes for the sampling area were from $113^{\circ} 15^{\prime} 31.08^{\prime \prime}$ to $126^{\circ} 30^{\prime} 52.43^{\prime \prime}$, and the latitudes ranged from $23^{\circ} 50^{\prime} 26.85^{\prime \prime}$ to $45^{\circ} 46^{\prime} 18.01$. The sites represented typical water ecosystems of Eastern China.

\subsection{Sediment sampling and analyses}

Three surface sediments (about $5 \mathrm{~cm}$ ) were collected by a Peterson grab sampler. Samples at the same site were pooled and homogenized to obtain representative samples. All the samples were frozen and stored at $-20^{\circ} \mathrm{C}$ immediately on return from the field. The sediment samples were freeze drying by freezer dryer. The samples were homogenized before removing impurities. Representative sample were obtained for grinding with quartering methods (Zhang et al., 2013).

Sample $\mathrm{pH}$ was determined in sediment suspension in deionized water with ratio of sediment to water being 1:2.5 (Bai et al., 2009). Organic matter (OM) was measured by combustion at $550{ }^{\circ} \mathrm{C}$ for $4 \mathrm{~h}$ (Heiri et al., 2001). Samples $(0.1 \mathrm{~g}$, dry weight basis) were digested with $\mathrm{HNO}_{3}-\mathrm{HCl}-\mathrm{HF}$ (MARSXpress, CEM, USA) and measured using ICP-OES/MS for total Fe, Al, Mg, Mn, Ca (DuzgorenAydin et al., 2011). Measurement of TP in sediment was based on treatment at $500^{\circ} \mathrm{C}(2 \mathrm{~h})$, followed by $\mathrm{HCl}\left(1 \mathrm{~mol} \mathrm{~L}^{-1}\right)$ extraction $(16 \mathrm{~h})$. For inorganic $\mathrm{P}(\mathrm{Pi})$, samples were extracted $(16 \mathrm{~h})$ with $\mathrm{HCl}$ $\left(1 \mathrm{~mol} \mathrm{~L}^{-1}\right)$. Organic $\mathrm{P}(\mathrm{Po})$ concentrations in the sediments were calculated as the difference between TP and Pi (Aspila et al., 1976). The $P$ in the respective extracts was measured by molybdate colorimetry (Murphy and Riley, 1962).

For solution ${ }^{31} \mathrm{P}-\mathrm{NMR}$ analysis, sediment sample $(3.0 \mathrm{~g})$ was extracte with $30 \mathrm{ml}$ of $0.05 \mathrm{~mol} \mathrm{~L}^{-1} \mathrm{EDTA}+0.25 \mathrm{~mol} \mathrm{~L}^{-1} \mathrm{NaOH}$ for $16 \mathrm{~h}$ at room temperature (Cade-Menun and Preston, 1996). An aliquot of the extracts was used to measure $\mathrm{Pi}$ (Pi in NaOH-EDTA) and TP (TP in NaOH-EDTA). Pi was determined in diluted extracts by molybdate colorimetry (Murphy and Riley, 1962). The Pi fraction is mainly ortho-P but can include acid-labile organic and condensed P compounds (Dick and Tabatabai, 1977). TP was measured by a similar procedure after acid-persulphate digestion of the samples (Rowland and Haygarth, 1997). Po was calculated as the difference between TP and Pi. Thus, the Po were overestimated, 
because the poly-P and pyro-P were not react with color reagent (Cade-Menun and Liu, 2013; Shand et al., 2000). So the P in the sediment may be divided into molybdate-reactive P (MRP) and molybdate-unreactive P (MUP) (Cade-Menun and Liu, 2013; Haygarth and Sharpley, 2000). However, we use the terms Pi and Po for clarity as in Turner et al. (2003a). The remaining solutions were frozen and lyophilized for subsequent ${ }^{31} \mathrm{P}-\mathrm{NMR}$ analysis. Freezing the extracts has been shown not to alter the $\mathrm{P}$ components composition (Hupfer et al., 1995, 2004; Shinohara et al., 2012).

The lyophilized $\mathrm{NaOH}-\mathrm{EDTA}$ extracts $(300 \mathrm{mg})$ were re-


sonicated for $30 \mathrm{~min}$ and then equilibrated for $5 \mathrm{~min}$. A $2 \%(\mathrm{v} / \mathrm{v})$ solution of $\mathrm{BD}\left(0.11 \mathrm{M} \mathrm{NaHCO}_{3}+0.11 \mathrm{M} \mathrm{Na}_{2} \mathrm{~S}_{2} \mathrm{O}_{4}\right)$ was added to the extracts for reducing paramagnetic ion $\left(\mathrm{Fe}^{3+}, \mathrm{Mn}^{2+}\right)$ interference (Zhang et al., 2013). The supernatants were centrifuged for $15 \mathrm{~min}$ at $14,000 \mathrm{rpm}$ and transferred to $5 \mathrm{~mm}$ NMR tubes. Solution ${ }^{31} \mathrm{P}$ NMR spectra were obtained using a Bruker $400 \mathrm{MHz}$ spectrometer (Bruker, Billerica, MA, USA) operating at $129.53 \mathrm{MHz}$ at $25^{\circ} \mathrm{C}$. Measurement parameters included a $90^{\circ}$ observation pulse, a relaxation delay of $3.6 \mathrm{~s}$ and an acquisition time of $0.6 \mathrm{~s}$. Spectra were acquired based on about 20,000 scans (Beijing NMR center). Chemical shifts were recorded relative to $85 \% \mathrm{H}_{3} \mathrm{PO}_{4}$ standard $(\delta=0 \mathrm{ppm})$. Signals were assigned to $\mathrm{P}$ components based on the literatures (Cade-Menun, 2005,b; Turner et al., 2003a,b). The peak area responses for samples were calculated based on visual inspection and an automated peak analysis routine. Based on the differing peak area responses for each $\mathrm{P}$ components, the contribution of each components (phosphonate: phon-P, orthophosphate: ortho-P, orthophosphate monoesters (inositol phosphates, sugar phosphates and phosphoproteins): mono-P, orthophosphate diesters (lipids-P and DNA-P): diester-P, pyrophosphate: pyro-P and polyphosphates: ploy-P) was calculated relative to the TP in the NaOH-EDTA extraction, as determined by the molybdenum blue method (Turner et al., 2005; Cade-Menun et al., 2005).

\subsection{Laboratory Experiments}

\subsubsection{Phosphorus sorption capacity of sediment}

Six subsamples of dry sediment $(1.0 \mathrm{~g})$ were well mixed with $40 \mathrm{ml}$ of $\mathrm{KH}_{2} \mathrm{PO}_{4}$ solution containing $0,5,10,20,30,50 \mathrm{mg} \mathrm{PL}^{-1}$, respectively, by magnetic stirring for $24 \mathrm{~h}$ at $25^{\circ} \mathrm{C}$ (Liu et al., 2009). The slurry was filtered and the $\mathrm{P}$ in the supernatant was measured by molybdate colorimetry. The difference between $P$ concentrations before and after the procedure was assumed to have been sorbed. The sorption data were fitted to the Langmuir equation to calculate the Xm value. Sediment P saturation (SPS) was calculated as the TP:(Xm+TP) ratio (Kopáček et al., 2005; Liu et al., 2009), where

$\mathrm{SPS}=\mathrm{TP} /(\mathrm{Xm}+\mathrm{TP}) \times 100 \%$

\subsubsection{Eutrophication risk index (ERI)}

The ERI was used to assess the risk of eutrophication. In this study, the ERI was calculated as the ratio of SPS to Xm, where

$\mathrm{ERI}=\mathrm{SPS} / \mathrm{Xm} \times 100 \%$

Huang et al. (2004) showed that the ERI can be classified into four grades: ERI $>25$ (highest risk), $25>E R I>20$ (higher risk), $20>$ ERI $>10$ (moderate risk), ERI $<10$ (low risk).

\subsection{Statistical analysis}

The experimental data were analyzed using SPSS 19.0 for Windows. Spearman's correlation was used to assess the relationship between the phosphorus and sediment properties. The Biplot was analyzed by SAS for windows 9.2 (SAS Institute, Inc., Cary, NC, USA). The vector length in Biplot shows the measure ability of variable for distinguishing the environmental factors. The angle between two environment vectors indicated the relationship between two vectors. All analysis was performed using standard procedure in Microsoft Excel.

\section{Results}

\subsection{Sediment properties}

The $\mathrm{pH}, \mathrm{OM}$, and the concentrations of TP, Po, $\mathrm{Al}, \mathrm{Ca}, \mathrm{Fe}, \mathrm{Mg}$ and $\mathrm{Mn}$ are shown in Table 1 . The $\mathrm{pH}$ was higher in estuary samples than other samples, which were 8.10 and 8.35 . The OM changed dramatically, which ranged from $3.0 \pm 0.0 \%$ to $14.4 \pm 1.1 \%$. The average concentration of TP was $1207.1 \mathrm{mg} \mathrm{kg}^{-1}$. The high concentrations of $\mathrm{TP}$ were in river sediments, which were $3837.2 \pm 46.5 \mathrm{mg} \mathrm{kg}^{-1}$ and $5127.3 \pm 81.6 \mathrm{mg} \mathrm{kg}^{-1}$ in sites 5 and 12 , respectively. The average concentration of Po was $182.7 \mathrm{mg}$ $\mathrm{kg}^{-1}$. The high concentrations of Po were in river sediments, which were $909.6 \pm 15.4 \mathrm{mg} \mathrm{kg}^{-1}$ in site 5 .

The Po accounted for 3.0\%-35.5\% of TP for all the sediment samples. The concentrations of $\mathrm{Ca}, \mathrm{Mg} \mathrm{Mn}$ were much lower than $\mathrm{Al}$ and $\mathrm{Fe}$, the concentrations of which were 7.4, 4.0, 0.8, 45.0 and $36.4 \mathrm{~g} \mathrm{~kg}^{-1}$.

Table 1

Characteristics of the sediments used in this study.

\begin{tabular}{|c|c|c|c|c|c|c|c|c|c|c|c|}
\hline Site & $\mathrm{pH}$ & $\begin{array}{l}\mathrm{OM} \\
\%\end{array}$ & $\begin{array}{l}\mathrm{TP}^{\mathrm{a}} \\
\mathrm{mg} \mathrm{kg}^{-1}\end{array}$ & Po $(\%)^{b}$ & $\begin{array}{l}\mathrm{Al} \\
\mathrm{g} \mathrm{kg}^{-1}\end{array}$ & $\mathrm{Ca}$ & $\mathrm{Fe}$ & $\mathrm{Mg}$ & $\mathrm{Mn}$ & $\begin{array}{l}\mathrm{Xm} \\
\mathrm{mPkg}{ }^{-1}\end{array}$ & $\begin{array}{l}\text { SPS } \\
\%\end{array}$ \\
\hline 1 & 7.27 & $4.4 \pm 0.2^{c}$ & $567.6 \pm 11.2$ & $46.4 \pm 1.2(8.2)$ & $60.0 \pm 1.9$ & $2.7 \pm 0.1$ & $31.1 \pm 0.6$ & $3.4 \pm 0.3$ & $0.73 \pm 0.01$ & 259.4 & 68.6 \\
\hline 2 & 6.92 & $11.6 \pm 1.1$ & $630.7 \pm 22.5$ & $224.0 \pm 10.7(35.5)$ & $4.3 \pm 0.7$ & $19.1 \pm 1.2$ & $40.2 \pm 1.1$ & $2.4 \pm 0.3$ & $1.89 \pm 0.07$ & 997.5 & 38.7 \\
\hline 3 & 8.10 & $3.1 \pm 0.1$ & $554.6 \pm 12.7$ & $50.7 \pm 2.1(9.2)$ & $27.6 \pm 2.3$ & $8.0 \pm 1.8$ & $29.2 \pm 0.4$ & $4.2 \pm 1.0$ & $0.59 \pm 0.01$ & 135.0 & 80.4 \\
\hline 4 & 8.35 & $3.0 \pm 0.0$ & $515.0 \pm 21.7$ & $56.3 \pm 4.8(9.9)$ & $19.1 \pm 0.7$ & $8.6 \pm 1.1$ & $30.7 \pm 0.5$ & $3.2 \pm 0.2$ & $0.58 \pm 0.01$ & 100.4 & 83.7 \\
\hline 5 & 7.25 & $14.4 \pm 1.1$ & $3837.2 \pm 46.5$ & $909.6 \pm 15.4(19.2)$ & $30.2 \pm 0.5$ & $5.1 \pm 0.3$ & $51.7 \pm 1.2$ & $3.7 \pm 0.2$ & $0.51 \pm 0.01$ & 1000.0 & 79.3 \\
\hline 6 & 7.65 & $7.5 \pm 1.1$ & $938.2 \pm 12.5$ & $225.9 \pm 21.1(19.4)$ & $2.2 \pm 0.6$ & $22.3 \pm 1.6$ & $21.9 \pm 1.4$ & $2.5 \pm 0.3$ & $0.34 \pm 0.01$ & 305.1 & 75.5 \\
\hline 7 & 8.51 & $5.6 \pm 0.3$ & $463.6 \pm 22.2$ & $133.0 \pm 1.1(22.3)$ & $31.2 \pm 0.3$ & $7.1 \pm 0.4$ & $29.3 \pm 1.4$ & $4.2 \pm 0.1$ & $0.42 \pm 0.02$ & 297.2 & 60.9 \\
\hline 8 & 6.87 & $5.8 \pm 0.1$ & $311.4 \pm 11.1$ & $130.6 \pm 6.5(29.5)$ & $69.4 \pm 1.5$ & $3.1 \pm 0.0$ & $36.5 \pm 0.8$ & $6.0 \pm 0.1$ & $1.34 \pm 0.02$ & 517.5 & 37.5 \\
\hline 9 & 6.86 & $7.5 \pm 1.0$ & $240.9 \pm 7.7$ & $70.5 \pm 3.9(22.7)$ & $102.2 \pm 1.2$ & $1.3 \pm 0.2$ & $44.2 \pm 0.5$ & $5.5 \pm 0.5$ & $0.80 \pm 0.01$ & 318.5 & 43.0 \\
\hline 10 & 7.27 & $4.5 \pm 0.8$ & $903.0 \pm 10.7$ & $27.8 \pm 2.2(3.0)$ & $57.1 \pm 2.4$ & $4.0 \pm 0.1$ & $39.5 \pm 1.2$ & $5.1 \pm 0.2$ & $0.73 \pm 0.03$ & 401.2 & 69.2 \\
\hline 11 & 6.81 & $4.5 \pm 0.3$ & $395.6 \pm 5.5$ & $107.7 \pm 6.1(21.4)$ & $56.8 \pm 1.5$ & $4.0 \pm 0.1$ & $44.9 \pm 1.5$ & $4.7 \pm 0.1$ & $1.16 \pm 0.05$ & 319.0 & 55.3 \\
\hline 12 & 7.24 & $10.4 \pm 0.6$ & $5127.3 \pm 81.6$ & $210.4 \pm 3.6(3.9)$ & $80.2 \pm 2.6$ & $3.5 \pm 0.2$ & $37.5 \pm 1.1$ & $3.2 \pm 0.2$ & $0.48 \pm 0.03$ & 934.6 & 84.6 \\
\hline
\end{tabular}

a The concentration is based on the dry weight.

b The figures in brackets are the proportions of the Po to the TP concentrations in the sediments.

c The values are the means and standard deviations for three replicate determinations. 


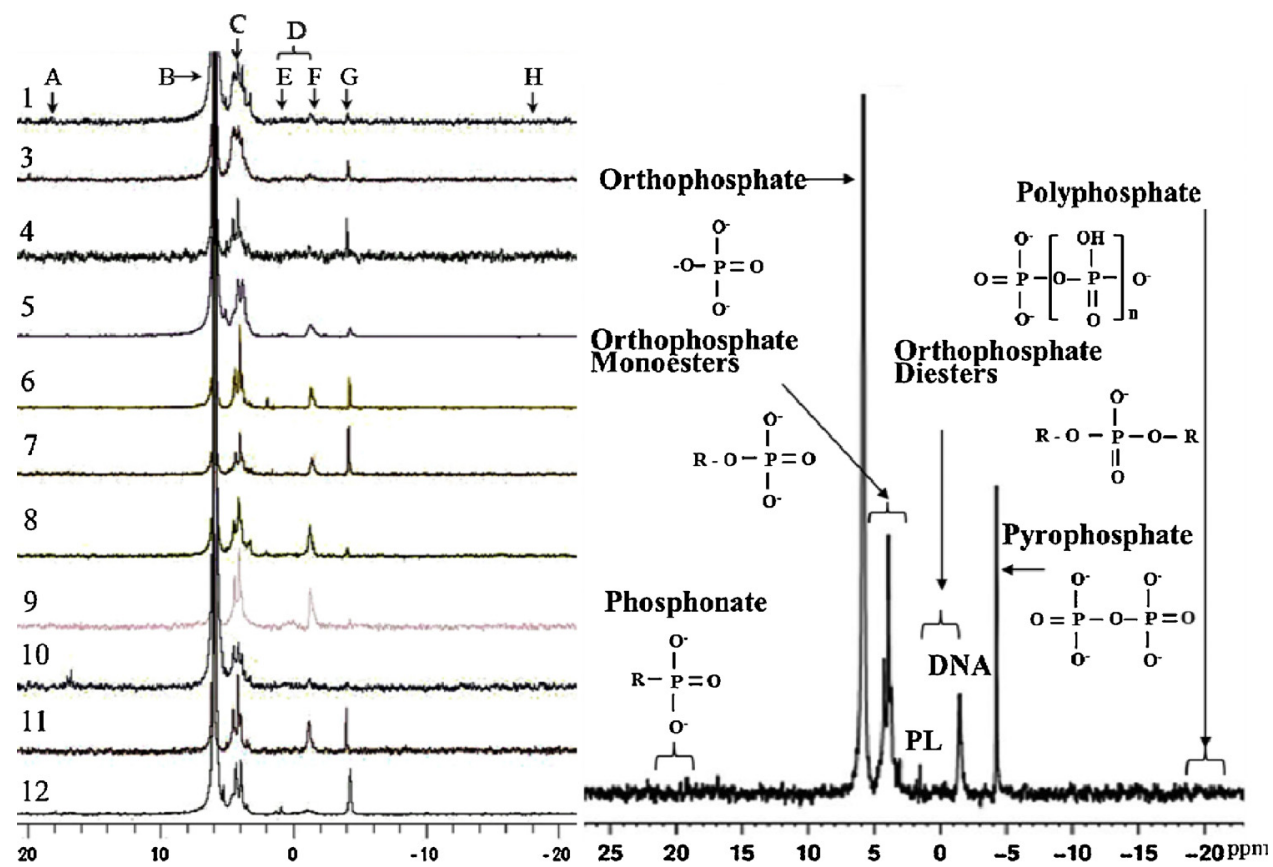

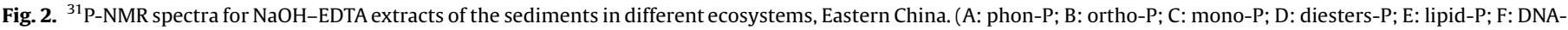
P; G: pyro-P; H: poly-P).

\subsection{Phosphorus ${ }^{31} P$-NMR assignments}

The NMR spectra for the sediments are shown in Fig. 2, where seven $\mathrm{P}$ compounds classes were detected in the $\mathrm{NaOH}-\mathrm{EDTA}$ extracts. These include: phon-P $(20 \mathrm{ppm})$, ortho-P $(6-7 \mathrm{ppm})$, mono-P (4-6 ppm), lipids-P (1-3 ppm), DNA-P (0 ppm), pyro-P ( -3.5 to $-4.5 \mathrm{ppm})$ and poly-P ( -17 to $-19 \mathrm{ppm}$ ) (Cade-Menun, 2005; Cade-Menun et al., 2006,c; Turner et al., 2003b,c), respectively. Phon-P was only detected at sites 10 and 11 . Poly-P was only found in site 11 .

The concentrations and relative distributions of the various $\mathrm{P}$ compounds in the different sediments are presented in Table 2. Po in the $\mathrm{NaOH}$-EDTA fraction ranged from 3.2 to $801.3 \mathrm{mg} \mathrm{kg}^{-1}$, which accounted for $2.4 \%-20.9 \%$ of the TP concentration in $\mathrm{NaOH}-$ EDTA extracts. The ortho-P was the dominant form of $\mathrm{P}$ in the
$\mathrm{NaOH}-\mathrm{EDTA}$ extracts of different sediments, and ranged from 119.6 to $4271.9 \mathrm{mg} \mathrm{kg}^{-1}$, accounting for $81.3-97.6 \%$ of TP in $\mathrm{NaOH}-$ EDTA extracts. The concentration of pyro-P was much less than ortho-P, ranging from 0.3 to $130.0 \mathrm{mg} \mathrm{kg}^{-1}$ and accounting for $0.0-$ $4.0 \%$ of TP in sediment extracts. Poly-P was only detected in site 11 , the concentration of which was $0.3 \mathrm{mg} \mathrm{kg}^{-1}$, and accounting for $0.2 \%$ of TP in sediment extracts. Mono-P was the dominant Po in the $\mathrm{NaOH}-\mathrm{EDTA}$ fraction of sediments, and ranged from 2.0 to $690.0 \mathrm{mg} \mathrm{kg}^{-1}$, accounting for $1.1-18.0 \%$ of TP in sediment extracts. DNA-P ranged from 0.6 to $74.0 \mathrm{mg} \mathrm{kg}^{-1}$, with relative contributions of $0.2-4.1 \%$ of the extracted $\mathrm{P}$ in the different sediments. Lipid-P ranged from 0.5 to $22.0 \mathrm{mg} \mathrm{kg}^{-1}$, with relative contributions being $0.3-0.8 \%$ of extracted $P$ in the sediments. Phon-P was only detected at site 10 , with concentrations of $2.4 \mathrm{mg} \mathrm{kg}^{-1}$, accounting for 0.4 of $\mathrm{TP}$ in the sediments, respectively.

Table 2

Concentrations $s^{\mathrm{a}}$ for $\mathrm{P}$ compounds in $\mathrm{NaOH}-\mathrm{EDTA}$ extracts of the sediments by ${ }^{31} \mathrm{P}-\mathrm{NMR}$.

\begin{tabular}{|c|c|c|c|c|c|c|c|c|c|}
\hline \multirow[t]{2}{*}{ Site } & \multirow{2}{*}{$\begin{array}{l}\mathrm{TP} \\
\mathrm{mg} \mathrm{kg}^{-1}\end{array}$} & \multirow[t]{2}{*}{ Po } & \multicolumn{3}{|l|}{ Inorganic-P } & \multicolumn{4}{|l|}{ Organic-P } \\
\hline & & & Ortho-P & Pyro-P & Poly-P & Mono-P & Lipid-P & DNA-P & Phon-P \\
\hline 1 & 367.5 & $36.1(9.8)^{b}$ & $331.4(90.2)^{c}$ & $0.5(0.1)$ & n.d. & $34.4(9.4)$ & n.d. & $1.2(0.3)$ & n.d. \\
\hline 2 & 322.6 & n.d. & n.d. & n.d. & n.d. & n.d. & n.d. & n.d. & n.d. \\
\hline 3 & 126.6 & $7.0(5.5)$ & $119.6(94.5)$ & $0.7(0.6)$ & n.d. & $6.3(4.9)$ & n.d. & 0.0 & n.d. \\
\hline 4 & 130.7 & $3.2(2.4)$ & $127.5(97.6)$ & $1.2(0.9)$ & n.d. & $2.0(1.5)$ & n.d. & 0.0 & n.d. \\
\hline 5 & 3838.1 & $801.3(20.9)$ & $3036.8(79.1)$ & $25.9(0.7)$ & n.d. & $690.0(18.0)$ & $11.4(0.3)$ & $74.0(1.9)$ & n.d. \\
\hline 6 & 490.0 & $82.4(16.8)$ & $407.5(83.2)$ & $5.5(1.1)$ & n.d. & $60.5(12.4)$ & $3.9(0.8)$ & $12.4(2.5)$ & n.d. \\
\hline 7 & 200.1 & $18.0(9.0)$ & $182.0(91.0)$ & $8.0(4.0)$ & n.d. & $2.3(1.1)$ & $0.5(0.3)$ & $7.3(3.6)$ & n.d. \\
\hline 8 & 253.2 & $47.2(18.7)$ & $205.9(81.3)$ & $1.0(0.4)$ & n.d. & $35.0(13.8)$ & $0.8(0.3)$ & $10.4(4.1)$ & n.d. \\
\hline 9 & 175.6 & $15.9(9.1)$ & 159.6(90.9) & n.d. & n.d. & $14.3(8.1)$ & $1.1(0.6)$ & $0.6(0.3)$ & n.d. \\
\hline 10 & 653.3 & $34.6(5.3)$ & $618.7(94.7)$ & n.d. & n.d. & $28.0(4.3)$ & $2.4(0.4)$ & $1.5(0.2)$ & $2.4(0.4)$ \\
\hline 11 & 285.8 & $22.8(8.0)$ & $263.3(92.1)$ & $1.1(0.4)$ & $0.6(0.20)$ & $18.3(6.4)$ & n.d. & $2.6(0.9)$ & n.d. \\
\hline 12 & 4961.0 & 689.1(13.9) & $4271.9(86.1)$ & $130.0(2.6)$ & n.d. & $495.9(10.0)$ & $22.0(0.4)$ & $41.3(0.8)$ & n.d. \\
\hline
\end{tabular}

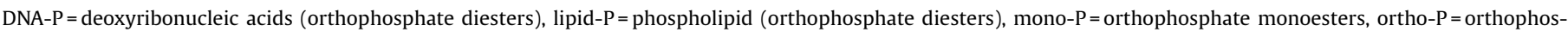
phate, phon $-\mathrm{P}=$ phosphonate, poly $-\mathrm{P}=$ polyphosphate, pyro- $\mathrm{P}=$ pyrophosphate .

a The value was calculated from the concentration in the $\mathrm{NaOH}-E D T A$ extract and the dry weight.

b The figures in brackets are the Po to TP concentrations in the NaOH-EDTA extracts.

c The proportion of individual $\mathrm{P}$ fraction to TP in sediment (\%). 


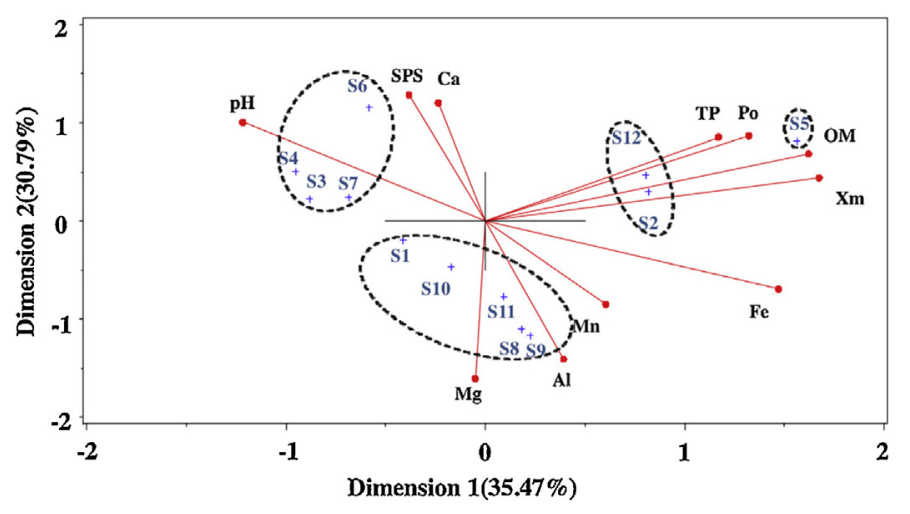

Fig. 3. Biplot of phosphorus, sediment properties, metal concentration in sediments and sample sites.

\subsection{Eutrophication risk}

In order to evaluate the eutrophication risk of the different sediments, the Xm, SPS and ERI were determined and the results are shown in Table 1 and Fig. 4. The sorption data fitted well to the Langmuir equation. The calculated Xm values ranged from 100.4 to $1000.0 \mathrm{mg} \mathrm{kg}^{-1}$. The high $\mathrm{Xm}$ values were for sites 5 and 12 , which were 1000.0 and $934.6 \mathrm{mg} \mathrm{P} \mathrm{kg}^{-1}$ and values had a similar trend with values for sediment P. The SPS values varied considerably from 38.7 to 84.6 , with an average SPS value of 65 . The ERI values ranged from 3 to 83 and the average was 24.The values for samples at 5 sites exceeded 20 (sites 1, 3, 4, 6 and 7), which meant the sites were at a high risk of eutrophication.

\section{Discussion}

\subsection{Phosphorus pollution in the sediments}

Phosphorus concentrations in the various sediments were quite different. In general, the concentrations of TP were higher in river sediments than other sediments. The concentrations of TP were 3837.2 and $5127.3 \mathrm{mg} \mathrm{kg}^{-1}$ in the Haihe and the Zhujiang, respectively. The the Haihe River Basin and the Zhujiang both have a large population and rapid economic growth rate and many large cities are located there. Moreover, environmental legislation, investment and sewage treatment has not kept pace with economic growth and the population increase. Therefore, large amounts of untreated wastewater and rubbish have been directly discharged to the environment. Consequently a large loading of $\mathrm{P}$ will be carried into the rivers (Liu and Raven, 2010; Qu and Fan, 2010). The river sampling sites in this research were in the flood plain. It should be noted that dams and irrigation channels have been constructed along the river, which makes the main water body flow much more slowly than would otherwise be the case. In some rivers in the Haihe River Basin for instance, there are some 18 dams in the Beiyunhe River over a 100 kilometer stretch (Pernet-Coudrier et al., 2012; Li et al., 2012 Zhang et al., 2013). The $P$ concentrations in the wetlands, lakes, reservoirs and estuaries were lower than that in the rivers. The average concentration of TP for the 8 sites was $500 \mathrm{mg} \mathrm{kg}^{-1}$ (sites $1-6,12$, and 10). The Po contents in the lakes, wetlands and reservoirs were higher than that in the rivers and the estuaries, and these values for Po surpassed $22 \%$ of the TP values. The Po in the estuaries was less than $10 \%$ of the TP values. The estuary is the region where seawater and freshwater mix, and where the $\mathrm{pH}$ and redox chemistry become complex, hence there would be an acceleration in the speed of Po transformation (Suzumura and Kamatani, 1993; Monbet et al., 2009). Sites 10 and 11 represented the water inlet and water outlet in an artificial wetland, respectively. The TP concentration was high in the water inlet but low in the water outlet, being 902 and $395 \mathrm{mg} \mathrm{kg}^{-1}$, respectively. On the contrary, the concentration of Po was low in the water inlet and high in the water outlet, being 27 and $107 \mathrm{mg} \mathrm{kg}^{-1}$, respectively. This result indicated that the wetland can withhold large amounts of Pi, but the Po will increase after the wetland, because of plant and microorganism metabolic activity (Cheesman et al., 2010).

The Biplot of phosphorus, sediment properties, metal concentration in sediment and sample sites are shown in Fig. 3. The first principal component account for $35.47 \%$, and second principal component account for $30.79 \%$. Two principal components accounted for $66.26 \%$, which belongs to batter fitting level (Wang et al., 2013a,b,b). The angles between environment variable show that TP and Po, OM and $\mathrm{Xm}$ have positive relationship. The results indicated the $\mathrm{OM}$ is vital factor for $\mathrm{P}$ distribution. The positive relationship are also found between SPS and Ca, indicating the SPS

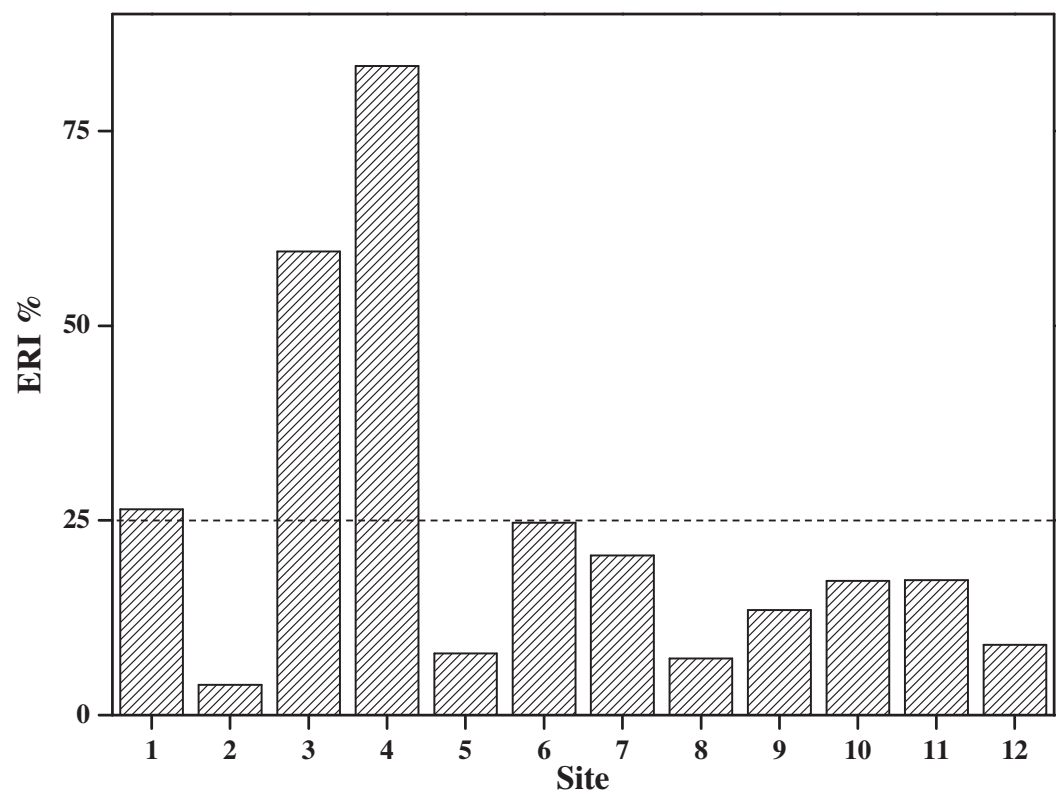

Fig. 4. Phosphorus-induced up-water eutrophication risk index for surface sediment in various sites. 
Table 3

Pearson correlation coefficients for physicochemical characteristics, P and metal concentrations in the sediment ( $n=132$ ).

\begin{tabular}{|c|c|c|c|c|c|c|c|c|c|c|c|}
\hline & $\mathrm{pH}$ & $\mathrm{OM}$ & $\mathrm{TP}$ & Po & $\mathrm{Al}$ & $\mathrm{Ca}$ & $\mathrm{Fe}$ & $\mathrm{Mg}$ & $\mathrm{Mn}$ & $\mathrm{Xm}$ & SPS \\
\hline $\mathrm{pH}$ & 1 & -.394 & -.112 & -.140 & -.499 & .206 & $-.644^{*}$ & -.289 & $-.606^{*}$ & -.486 & .569 \\
\hline $\mathrm{OM}$ & & 1 & $.669^{*}$ & $.815^{* *}$ & -.088 & .213 & .536 & -.341 & .145 & $.916^{* *}$ & -.067 \\
\hline $\mathrm{TP}$ & & & 1 & $.616^{*}$ & .138 & -.145 & .334 & -.307 & -.341 & $.698^{*}$ & .521 \\
\hline Po & & & & 1 & -.240 & .084 & .520 & -.237 & -.130 & $.669^{*}$ & .208 \\
\hline $\mathrm{Al}$ & & & & & 1 & $-.827^{* *}$ & .408 & $.684^{*}$ & -.010 & -.013 & -.259 \\
\hline $\mathrm{Ca}$ & & & & & & 1 & -.465 & $-.706^{*}$ & .138 & .107 & .021 \\
\hline $\mathrm{Fe}$ & & & & & & & 1 & .344 & .355 & .573 & -.289 \\
\hline $\mathrm{Mg}$ & & & & & & & & 1 & .112 & -.270 & -.446 \\
\hline $\mathrm{Mn}$ & & & & & & & & & 1 & .342 & $-.788^{* *}$ \\
\hline $\mathrm{Xm}$ & & & & & & & & & & 1 & -.125 \\
\hline SPS & & & & & & & & & & & 1 \\
\hline
\end{tabular}

" Correlation is significant at the 0.05 level (2-tailed).

*** Correlation is significant at the 0.01 level (2-tailed).

may affected by the concentration of Ca in sediment. The sample sites divide into four groups. The first group is site 5 , which is a high polluted sediment sample and have high $\mathrm{P}$ concentration. The second group including sites 2 and 12, the concentration of OM in these sites are higher than other sites. Sites 3, 4, 6 and 7 belong to third group, which have high and similar SPS. The last groups including sites $1,8,9,10$ and 11 . The relationship between physicochemical characteristics, $\mathrm{P}$ and metal concentration was analyzed by Pearson's correlation (Table 3 ). The results also show that the Po and $\mathrm{Xm}$ were found to be significant positively correlated with $\mathrm{OM}(p<0.01)$, which indicated the organic matter is vital element for the $\operatorname{TP}(p<0.01)$ and $\mathrm{Po}(p<0.01)$ distribution.

The P compounds showed diversity in the different sediments. The ortho-P was most prominent in the surface sediment. Pyro-P was detected in most sediment. Poly-P was only found in the water outlet of the artificial wetland. Some studies suggested that the pyro-P may originate from poly-P and esters, which can be hydrolyzed during alkaline extraction (Hupfer et al., 1995, 2004), so the poly-P may be hydrolyzed during $\mathrm{NaOH}-\mathrm{EDTA}$ extraction and not detected by the ${ }^{31} \mathrm{P}-\mathrm{NMR}$ in most of samples. The majority of Po originated from mono-P compounds, and this species was detected at all sites. Mono-P comprised $1.1 \%-18 \%$ of TP in NaOH-EDTA extract. Mono-P represents an important Po compounds in the sediment, which includes inositol $\mathrm{P}$, sugar phosphates and mononucleotides. Inositol phosphates were considered to be the most abundant Po in aquatic sediment, and these compounds can be mineralized under anaerobic or aerobic conditions (Turner et al., 2002). Diester-P is a mixture of numerous compounds with varying liability, including DNA-P and lipid-P, and these components were detected in rivers, lakes and wetlands but not in the estuaries. DNA-P and lipid-P were considered to have originated from an organism's basic metabolism (Shinohara et al., 2012). Rivers, lakes and wetlands have large algae and hydrophytes, which may have been the main sources of the DNA-P and lipid-P. DNA-P and lipid-P were not detected in the estuaries. The reason for this may be that the complex physical and chemical conditions existing in the estuary would induce the hydrolysis of the DNA-P and lipid-P (Monbet et al., 2009). The phon-P, which is a chemically stable compound because of the direct $\mathrm{C}-\mathrm{P}$ bond, was only found in the artificial wetland (Turner et al., 2005). Wetzel (2001) suggested that the $\mathrm{pH}$ may be important for the existence of phon$P$, because the bacteria which produce the phosphonatase enzyme would be controlled by the high $\mathrm{pH}$ conditions. In this study, however, the $\mathrm{pH}$ varied greatly.

\subsection{Eutrophication risk of the different sediments}

The eutrophication risk is different for the river, wetland, lake, estuary and reservoir. The release of $P$ in the surface sediment is governed by the sorption and desorption of $\mathrm{P}$ (Ramm and Scheps,
1997). According to the Chinese environmental dredging common standard, the sediments should be dredged and consequently have a high risk of P release (Liu et al., 1999). In this research, Xm, SPS and ERI were used to assess the P release risk in the different sediments. Generally, a high ERI means a high risk of P release, consequently there is a high eutrophication risk when the ERI surpass 25\% (Huang et al., 2004; Jin et al., 2006). The TP concentrations in samples from two-thirds of all sites exceeded $500 \mathrm{mg} \mathrm{kg}^{-1}$, including river water (sites $1,5,6,12$ ), estuary water (sites 3 and 4 ) and a reservoir water (site 2 ). The ERI values were greater than $25 \%$ for sites 1,3 and 4 , being 26,59 and $83 \%$, respectively. Sites 3 and 4 were on the Bohai estuary and are from a region where freshwater and sea-water mix, thus facilitating the release of P. So, the ERI in the estuary was higher than other regions. Although the concentrations of TP in site 3 (Miyun reservoir), which is a source of drinking water for Beijing, exceeded $500 \mathrm{mg} \mathrm{kg}^{-1}$, the ERI value represented a low risk condition. The main reason was that the depth of the Miyun reservoir was over $40 \mathrm{~m}$ and the hypolimnetic anoxia molar Al:Fe ratio was $<3$ (the value is 0.22 ), so the $P$ was stable and not readily released from the sediment (Kopáček et al., 2005). The ERI values at sites 5 and 12, which exhibited high TP concentrations, were lower than $10 \%$ indicating that they have a low eutrophication risk. Kopáček et al., found that the $\mathrm{P}$ would be released from lake sediment during hypolimnetic anoxia, if the molar $\mathrm{Al}_{\mathrm{NaOH}-25}: \mathrm{Fe}_{\mathrm{BD}}$ ratio was $>3$, or the molar $\mathrm{Al}_{\mathrm{NaOH}-25}: \mathrm{P}_{(\mathrm{H} 2 \mathrm{O}+\mathrm{BD})}$ ratio was $>25$. But oxidationreduction processes are different in lakes, rivers, estuaries and reservoirs. The Xm and the ERI gave a good fit for the power function $\left(R_{\mathrm{Xm} \text {-ERI }}=0.89, p<0.01\right)$ for all 12 sites (Fig. 5$)$. A positive relationship between $\mathrm{Xm}$ and $\mathrm{OM}$ in the sediment $\left(R_{\mathrm{Xm}-\mathrm{OM}}=0.84\right.$, $p<0.01$ ) indicated that the chemical-physical conditions, such as concentrations of organic matter (humic acid, fulvic acid and humin), play a vital role on $\mathrm{P}$ sorption and desorption.



Fig. 5. Correlation between Xm and ERI for the sediment samples. 


\section{Conclusions}

This research used ${ }^{31} \mathrm{P}-\mathrm{NMR}$ and sorption experiments to provide an insight into the occurrence of $\mathrm{P}$ components, their distribution and the risk of eutrophication in different water ecosystems, such as wetlands, lakes, reservoirs, rivers and estuaries in Eastern China. Results showed that the river sediments had accumulated significant amounts of TP and Po. Seven P compounds were detected in $\mathrm{NaOH}-$ EDTA extracts from the ${ }^{31} \mathrm{P}$ NMR analysis. Ortho-P (83.3-97.6\%) and mono-P (1.1-18.0\%) were the dominant $\mathrm{P}$ compounds, while smaller amounts of DNA-P (0$4.1 \%)$, pyro-P $(0-4.0 \%)$, lipid-P $(0-0.8 \%)$ were found in the surface sediment. Poly-P and phon-P were only detected at 3 sites (site 11 and site 10, respectively). The TP concentration in two-thirds of all sites exceeded $500 \mathrm{mg} \mathrm{kg}^{-1}$, which included river samples (sites $1,5,6,12$ ), estuarine samples (sites 3 and 4 ) and reservoir water (site 2). The ERI values were greater than $25 \%$ at sites 1, 3 and 4 , the values being 26, 59 and $83 \%$, respectively, hence these sites (sediments) have a high eutrophication risk. The Xm and ERI values were fitted to a power function $\left(R_{\mathrm{Xm} \text {-ERI }}=0.89, p<0.01\right)$ for all 12 sites and a positive correlation between Xm and OM in the sediment $\left(R_{\mathrm{Xm}-\mathrm{OM}}=0.84, \mathrm{p}<0.01\right)$.

\section{Acknowledgments}

This work was supported by Open Fund of Key Lab. of Contaminated Environment Control and Regional Ecology Safety (SYU-KF-L-07), Open Fund of Key Lab. of Regional Environment Eco-remediation, Education Ministry (SYU-KF-E-07) and the National Natural Scientific Foundation of China (21107126 and 20907067), and the National Water Pollution Control and Management Technology Major Projects of China (2012ZX07203-006 and 2012ZX07203-003). We thank Dr. Jingxin Yang and Dr. Xiaogang Niu for performing the ${ }^{31} \mathrm{P}-\mathrm{NMR}$ analysis (Beijing Nuclear Magnetic Resonance Center).

\section{References}

Ahlgren, J., Reitzel, K., Danielsson, R., Gogoll, A., Rydin, E., 2006. Biogenic phosphorus in oligotrophic mountain lake sediments: differences in composition measured with NMR spectroscopy. Water Res. 40, 3705-3712.

Aspila, K.I., Agemian, H., Chau, A.S.Y., 1976. A semi-automated method for the determination of inorganic organic and total phosphate in sediments. Analyst 101, 187-197.

Bai, X.L., Ding, S.M., Fan, C.X., Liu, T., Shi, D., Zhang, L., 2009. Organic phosphorus species in surface sediments of a large shallow, eutrophic lake, Lake Taihu, China. Environ. Pollut. 157, 2507-2513.

Cade-Menun, B.J., 2005. Characterizing phosphorus in environmental and agricultural samples by ${ }^{31} \mathrm{P}$ nuclear magnetic resonance spectroscopy. Talanta 66, 359-371.

Cade-Menun, B., Liu, C.W., 2013. Solution phosphorus-31 nuclear magnetic resonance spectroscopy of soils from 2005 to 2013: a review of sample preparation and experimental parameters. Soil Sci. Soc. Am. J. 78, 19-37.

Cade-Menun, B.J., Preston, C.M., 1996. A comparison of soil extraction procedures for ${ }^{31}$ P NMR Spectroscopy. Soil Sci. 161 (11), 770-785.

Cade-Menun, B.J., Benitez-Nelson, C.R., Pellechia, P., Paytan, A., 2005. Refining ${ }^{31} \mathrm{P}$ nuclear magnetic resonance spectroscopy for marine particulate samples: storage conditions and extraction recovery. Mar. Chem. 97, 293-306.

Cade-Menun, B.J., Navaratnam, J.A., Walbridge, M.R., 2006. Characterizing dissolved and particulate phosphorus in water with ${ }^{31} \mathrm{P}$ nuclear magnetic resonance spectroscopy. Environ. Sci. Technol. 40, 7874-7880.

Cheesman, A.W., Turner, B.L., Inglett, P., Reddy, K.R., 2010. Phosphorus transformations during decomposition of wetland macrophytes. Environ. Sci. Technol. 44, 9265-9271.

Dick, W.A., Tabatabai, M.A., 1977. Determination of orthophosphate in aqueous solutions containing labile organic and inorganic phosphorus compounds. J Environ. Qual. 6, 82-85.

Duzgoren-Aydin, N.S., Avula, B., Willett, K.L., Khan, I.A., 2011. Determination of total and partially extractable solid-bound element concentrations using collision/ reaction cell inductively coupled plasma-mass spectrometry and their significance in environmental studies. Environ. Monit. Assess. 172 (1-4), 51-66.

Haygarth, P.M., Sharpley, A., 2000. Terminology for phosphorus transfer. J. Environ. Qual. 29, 10-15.
Heiri, O., Lotter, A.F., Lemcke, G., 2001. Loss on ignition as a method for estimating organic and carbonate content in sediments: reproducibility and comparability of results. J. Paleolimnol. 25, 101-110.

Hong, Y., Luan, S.J., 1998. China's water security in the 21st century. J. China Environ. Manage. 4, 3-8.

Huang, Q.H., Wang, Z.J., Wang, D.H., Wang, C.X., Ma, M., 2004. Phosphorus sorption capacity of the surface sediment in the Lake Taihu and risk assessment of phosphorus release. J. Lake Sci. 16, 97-103.

Hupfer, M., Gächter, R., Ruegger, H., 1995. Polyphosphate in lake sediments: ${ }^{31}$ P NMR spectroscopy as a tool for its identification. Limnol. Oceanogr. 40, 610-617.

Hupfer, M., Rübe, B., Schmieder, P., 2004. Origin and diagenesis of polyphosphate in lake sediments: a ${ }^{31}$ P-NMR study. Limnol. Oceanogr. 49, 1-10.

Jin, X.C., Wang, S.R., Bu, Q.Y., Wu, F.C., 2006. Laboratory experiments on phosphorous release from the sediments of 9 lakes in the middle and lower reaches of Yangtze River region, China. Water, Air, Soil Pollut. 176, 233-251.

Kopáček, J., Borovec, J., Hejzlar, J., Ulrich, K.-U., Norton, S.A., Amirbahman, A., 2005 Aluminum control of phosphorus sorption by lake sediments. Environ. Sci. Technol. 39, 8784-8789.

Liu, J.G., Raven, P.H., 2010. China's environmental challenges and implications for the world. Crit. Rev. Env. Sci. Technol. 40, 823-851.

Liu, H.L., Jin, X.C., Jing, Y.F., 1999. Environmental dredging technology of lake sediment. Environ. Sci. 1, 81-84.

Liu, J.Y., Wang, H., Yang, H.J., Ma, Y.J., Cai, O.C., 2009. Detection of phosphorus species in sediments of artificial landscape lakes in China by fractionation and phosphorus-31 nuclear magnetic resonance spectroscopy. Environ. Pollut. 157, 49-56.

Li, N., Shan, B.Q., Zhang, H., Zhang, J.L., 2012. Organic phosphorus forms in the sediments in the downstream channels of north canal river watershed. Environ. Sci. 31, 2911-2916.

Ma, G.W., Wang, Y.Y., Xiang, B., Wang, J.S., Wang, T.M., Hu, Y., 2011. Diversity characteristic and pollution load of non-point source total nitrogen and total phosphorus in Songhua River Basin. Transact CSAE 27, 163-169 (in Chinese).

Monbet, P., McKelvie, I.D., Worsfold, P.J., 2009. Dissolved organic phosphorus speciation in the waters of the Tamar estuary (SW England). Geochim. Cosmochim. Acta 73, 1027-1038.

Murphy, J., Riley, J.P., 1962. A modified single solution method for determination of phosphate in natural waters. Analyt. Chim. Acta 26, 31-36.

Newman, R.H., Tate, K.R., 1980. Soil phosphorus characterization by ${ }^{31} \mathrm{P}$ nuclear magnetic resonance. Commun. Soil Sci. Plant Anal. 11, 835-842.

Nyenje, P.M., Foppen, J.W., Uhlenbrook, S., Kulabako, R., Muwanga, A., 2010. Eutrophication and nutrient release in urban areas of sub-Saharan Africa A review. Sci. Total Environ. 408, 447-455.

Paytan, A., McLaughlin, K., 2010. The oceanic phosphorus cycle. Chem. Rev. 107, $563-$ 576.

Pernet-Coudrier, B., Qi, W.X., Liu, H.J., Müller, B., Berg, M., 2012. Sources and pathways of nutrients in the semi-arid region of Beijing-Tianjin: China. Environ. Sci. Technol. 46, 5294-5301.

Qu, H.J., Kroeze, C., 2010. Past and future trends in nutrients export by rivers to the coastal waters of China. Sci. Total Environ. 408, 2075-2086.

Qu, J., Fan, M., 2010. The current state of water quality and technology development for water pollution control in China. Crit. Rev. Env. Sci. Technol. 40, 519-560.

Ramm, K., Scheps, V., 1997. Phosphorus balance of a polytrophic shallow lake with consideration of phosphorus release. Hydrobiologia 342/343, 43-53.

Rowland, A.P., Haygarth, P., 1997. Determination of total dissolved phosphorus in soil solutions. J. Environ. Qual. 26, 410-415.

Shand, C.A., Smith, S., Edwards, A.C., Fraser, A.R., 2000. Distribution of phosphorus in particulate: colloidal and molecular-sized fractions of soil solution. Water Res. $34,1278-1284$

Shi, Y.S., Xiao, J.Y., Shen, Y.J., 2008. Landscape pattern change and associated environmental implications in the Haihe River Basin, China. ISPRS J. Photogramm. Remote Sens. 37, 569-574.

Shinohara, R., Imai, A., Kawasaki, N., Komatsu, K., Kohzu, A., et al., 2012. Biogenic phosphorus compounds in sediment and suspended particles in a shallow eutrophic lake: ${ }^{31} \mathrm{P}$-nuclear magnetic resonance $\left({ }^{31} \mathrm{P}\right.$ NMR) Study. Environ. Sci. Technol. 46, 10572-10578.

Suzumura, M., Kamatani, A., 1993. Isolation and determination of inositol hexaphosphate in sediments from Tokyo Bay. Geochim. Cosmochim. Acta 57, 2197-2202.

Toor, D.S., Cade-Menun, B.J., Sims, J.T., 2005. Establishing a linkage between phosphorus forms in dairy diets feces, and Manures. J. Environ. Qual. 34, 13801391.

Turner, B.J., Papházy, M.J., Haygarth, P.M., Mckelvie, I.D., 2002. Inositol phosphates in the environment. Philos. Trans. R. Soc. B Biol. Sci. 57, 449-469.

Turner, B.L., Cade-Menun, B.J., Westermann, D.T., 2003a. Organic phosphorus composition and potential bioavailability in semi-arid arable soils of the western United States. Soil Sci. Soc. Am. J. 67, 1168-1179.

Turner, B.L., Mahieu, N., Condron, L.M., 2003b. Phosphorus-31 nuclear magnetic resonance spectral assignments of phosphorus compounds in soil $\mathrm{NaOH}-\mathrm{EDTA}$ extracts. Soil Sci. Soc. Am. J. 67, 497-510.

Turner, B.L., Mahieu, N., Condron, L.M., 2003c. The phosphorus composition of temperate pasture soils determined by $\mathrm{NaOH}-E D T A$ extraction and solution ${ }^{31} \mathrm{P}$ NMR spectroscopy. Org. Geochem. 34, 1199-1210.

Turner, B.L., Cade-Menun, B.J., Condron, L.M., Newman, S., 2005. Extraction of soil organic phosphorus. Talanta 66, 294-306. 
Vörösmarty, C.J., McIntyre, P.B., Gessner, M.O., Dudgeon, D., Prusevich, A., Green, P. Glidden, S., Bunn, S.E., Sullivan, C.A., Liermann, R.C., Davies, P.M., 2010. Globa threats to human water security and river biodiversity. Nature 467, 555-561.

Wang. J.Y. Pant, H.K., 2010a. Identification of organic phosphorus compounds in the Bronx River bed sediments by phosphorus-31 nuclear magnetic resonance spectroscopy. Environ. Monit. Assess. 171, 309-319.

Wang, J.Y., Pant, H.K., 2010b. Phosphorus sorption characteristics of the Bronx River bed sediments. Chem. Speciation Bioavailability 22, 171-181.

Wang, L.L., Ye, M., Li, Q.S., Zou, H., Zhou, Y.S., 2013a. Phosphorus speciation in wetland sediments of Zhujiang (Pearl) River estuary, China. Chin. Geog. Sci. 23 , 574-583.

Wang, Y., Wang, B.L., Peng, W.X., Wang, W.D., Yin, C.Q., 2013b. Biodegradability of organic matter in Shijiuyang wetland during winter. Acta Sci. Circumst. 10, $2774-2785$.

Wetzel, R.G., 2001. The phosphorus cycle. In: Wetzel, R.G. (Ed.), Limnology, Lake and River Ecosystem. Academic Press, San Diego, California, pp. 239-286.
Xu, H., Paerl, W.H., Qin, B.Q., Zhu, G.W., Gao, G., 2010. Nitrogen and phosphorus inputs control phytoplankton growth in eutrophic Lake Taihu, China. Limnol. Oceanogr. 55, 420-432.

Zhang, R.Y., Wu, F.C., He, Z.Q., Zheng, J., Song, B.A., Jin, L.H., 2009. Phosphorus composition in sediments from seven different trophic lakes, China: a phosphorus-31 NMR study. J. Environ. Qual. 38, 353-359.

Zhang, W.Q., Shan, B.Q., Zhang, H., Tang, W.Z., 2013. Assessment of preparation methods for organic phosphorus analysis in phosphorus-polluted Fe/Al-rich Haihe River sediments using solution ${ }^{31}$ P-NMR. PLoS One 8, e76525.

\section{Further reading}

Jensen, H.S., Kristensen, P., Jeppesen, E., Skytthe, A., 1992. Iron:phosphorus ratio in surface sediment as an indicator of phosphate release from aerobic sediments in shallow lakes. Hydrobiologia 235/236, 731-743. 